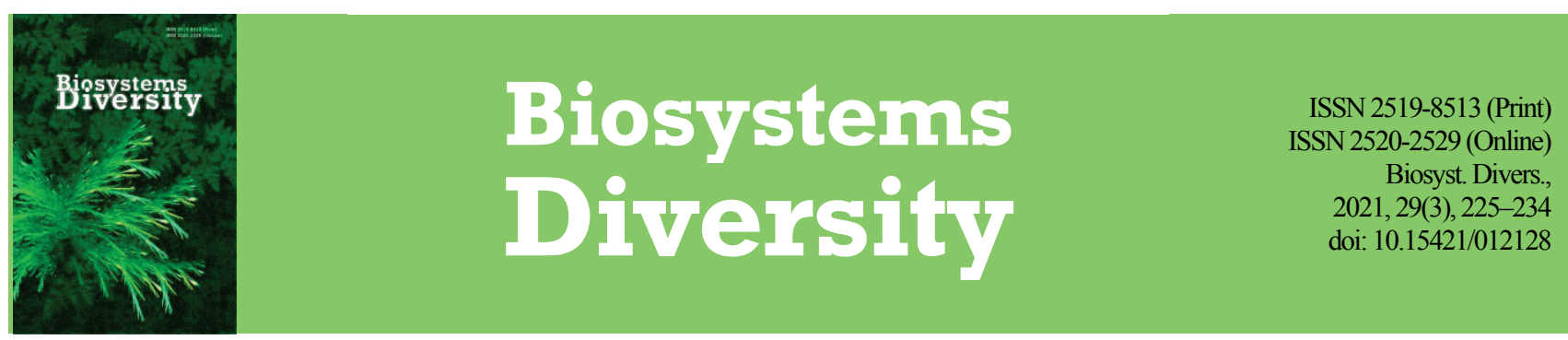

\title{
Taxonomic and ecological composition of the native groupings of the birds of the dry steppe zone of Ukraine
}

\author{
Y. O. Andryushchenko
}

\author{
Schmalhausen Institute of Zoology, Kyiv, Ukraine
}

\section{Article info \\ Received 08.07.2021 Received in revised form 11.08.2021 Accepted 14.08.2021}

Schmalhausen Institute of Zoology, B. Khmelnytskogo st., 15 , Kyiv, 01030, Ukraine.

Tel.: +38-050-199-95-06 E-mail: anthropoides73@gmail.com

\section{Andryushchenko, Y. O. (2021). Taxonomic and ecological composition of the native groupings of the birds of the dry steppe zone of Ukraine. Biosystems Diversity, 29(3), 225-234. doi:10.15421/012128}

The classifications of the grouping of the birds reflect the faunistic or the ecological position of the species in certain habitats and landscapes. Most of them consider the species diversity of the birds of the studied regions in general, including synanthropic, invasive and widespread species. This approach prevents singling out the habitats which are important for supporting the existence of native (or autochtonous) species and their groupings. Native groupings of the birds in the dry steppe zone of Ukraine are almost not studied despite the rapid contraction in the range and population of most component species, especially Anthropoides virgo, Otis tarda, Tetrax tetrax and Burhinus oedicnemus. The definition of the taxonomic and the ecological composition of these grouping will help in understanding the strategy of the reproduction and the protection of native avifauna. In connection with this, the faunistic-topomorphic classification of native birds in the dry steppes zone of Ukraine according to the following scheme is proposed: ornithofaunistic complex (by priority landscapes and habitats) the place of the feeding (by priority substrate on/in which a species' diet is extracted) - the nesting place (by the priority substrate of the location of the nest for nesting individuals) - the place of rest (the priority substrate where non-nesting individuals rest). The classification is aimed at the definition of the general requirements of native birds and their groupings in terms of the landscapes and the habitats which provide the conditions for their preservation and the protection in the researched region. It has been determined that in the south of Ukraine 33 nesting species are dry-steppe autochthons (18.3\% of nesting species of the region), of which 18 species form the ornithofaunistic complex of dry steppes (Buteo rufinus, Perdix perdix, Anthropoides virgo, Otis tarda, Tetrax tetrax, Burhinus oedicnemus, Glareola nordmanni, Galerida cristata, Calandrella cinerea, C. rufescens, Melanocorypha calandra, Anthus campestris, Motacilla feldegg, Saxicola rubetra, $S$. torquata, Oenanthe oenanthe, Oe. isabellina, Emberiza melanocephala), and 15 species form the complex of the sea coast (Phalacrocorax aristotelis, Phoenicopterus roseus, Tadorna ferruginea, T. tadorna, Mergus serrator, Charadrius alexandrinus, Recurvirostra avosetta, Larus ichthyaetus, L. melanocephalus, L. genei, L. cachinnans, L. michahellis, Gelochelidon nilotica, Hydroprogne caspia, Thalasseus sandvicensis). The above-mentioned species are mainly xerophiles (54.6\% of species) and hygrophils ( $24.2 \%$ of species), and they are in the most threatened position because they feed, nest and rest mainly or exclusively on the soil surface. According to the proposed classification, native birds of dry steppes require: for xerophiles - areas of soil without vegetation or with rarefied low grass, which does not prevent birds from moving freely, searching and obtaining food, leading their chicks, looking over their territories; for hygrophiles - shallow water bodies with islands, surface vegetation, shallows, adjacent meadows and salt-marshes; for dendrophiles - single shrubs and trees or small groves; for most xerophiles and dendrophiles - fresh or slightly saline water bodies for drinking. Unfortunately, in the protected natural territories of the researched region, most native birds do not have this combination of the above-mentioned habitats, which are simultaneously suitable for feeding, nesting and resting.

Keywords: vulnerable species; ornithofaunistic complexes; topomorphs; landscapes; habitats.

\section{Introduction}

A variety of names have been used to indicate the animal components of the biocoenosis (biotope, community, etc.): "animal community" (Shelford, 1913), "animal presociety" (Shelford \& Towler, 1926), "animal presocies" (Smith, 1928). With the development of ecological knowledge many classifications have appeared of ecological group of the animals, in particular, by their relation to their place of residence or habitats (topomorphs), chemistry of environment (chemomorphs), weather-climatic conditions (climamorphs), ways of feeding (tropomorphs), and so on. Thus, Akimov (1954) according to habitats divides the animals into hydrobionts or aquatic (limnophiles, potamophiles, rheophiles) and aerobionts, which are inhabitants of the air environment (hydrophiles, species inhabiting the shoreline of water bodies; hygrophiles are water-loving, living on/in dampish soil; drimiophiles are forest species which inhabit woody and shrub vegetation; poyophils are inhabitants of grass areas and deserts, and ubiquists are species which live everywhere). Aerobionts by the place of the residence are divided into phyllobionts (in tree crowns), cormobionts (on trunks), hortobionts (in grass), herpetobionts (in ground litter), pedobionts (on soil) and edaphobionts (in soil). But the birds, be- longing to aerobionts, are able to use most of the above mentioned environments at the same time and, so, among vertebrates most effectively occupy space, and first of all, its volumetric indicators, thanks to their high speed of the movement (Poznanin, 1978).

In ornithology, the communities of the birds of small territories or separate locations have been considered as "avifauna", "bird population", "ornithofaunistic complexes". The latter concept "ornithological complex" or "ornithocomplex" appeared only in the second half of the XX century, with the rapid development of the ecological knowledge (Tashliev, 1973). In due course, many approaches to the apportionment of the certain ornithocomplexes, from the faunistic to purely ecological appeared. From the faunistic point of view, the birds are divided into faunistic (ornithofaunistic) complexes according to the historical connections with the certain landscapes, depending on the history of their formation, the distribution of the ecological conditions in them, the presence of the physical obstacles for resettlement, etc. (Voinstvensky, 1960). Shulpin (1940) and then Ilyichev et al. (1982) proposed to divide the birds into ecological groups of species, based on the types of the landscapes and the peculiarities of movement in the process of forage extraction which is desirable for their nesting such as wood-shrub, terrestrial-wood, terrestrial, near-water, and 
also the species which hunt in the air. Poznanin (1978) noted that within each ecological group there is a great diversity by habitats of affiliation, by the place of nesting and by the types of the nests, the dietary complex and the ways of obtaining food, which correlates with many peculiarities such as the proportions of the limbs and the nature of their movement, the plumage properties, the shape of the beak and the tongue, the details of the structure of the digestive system, the structure of the receptors, etc. Thomas et al. (1979) considered that the distribution of birds into ecological groups depended not only on the place of feeding and the methods of forage extraction, but also on the composition of the principal diet. Belik (1992) put the location of the nest in the first place, and the place of the feeding is in the second place. Besides the provision of the proper resources for feeding and reproduction, the individual species and the grouping of the birds in general also depend on the protective conditions of the environment, in particular, on the negative effects of the weather and the predators (Hilden, 1965). According to Kochelev \& Pakhomov (2020), ornithocomplexes are historically composite groupings of birds of different species that have existed for a long time in particular territories and they are functionally interconnected. Obviously, due to the different meanings of the term of "ornithocomplex", Chernov (2008) proposed to reject its use in general.

There is a number of hypotheses for the organization of the composition of grouping of animals (Legendre et al., 2005). The diversity of groupings of animals is determined by the landscape structure (Morante-Filho et al., 2016), but the reasons of the distribution of the species by the habitats vary significantly between the landscapes (Jankowski et al., 2009; Morante-Filho et al., 2016). In particular, a grouping is distributed along the ecological gradients (Lennon et al., 2001; Zhukov \& Potapenko, 2017), for example, along the height gradient (Blake \& Loiselle, 2000; Heaney, 2001; McCain, 2004) and it depends on the changes of the agricultural activity or climate (Karp et al., 2018; Koshelev et al., 2021). Research on regional species diversity gives an opportunity to compare the differences in the composition between the different groupings (Whittaker, 1960, 1972). The understanding of the mechanisms which affect the species diversity is an important for the detection of the patterns of the dynamics of the regional biodiversity (Jamoneau et al., 2018; Negadi et al., 2018; Ponomarenko et al., 2021). The estimate of the differentiation of the distribution of the species by the gradients of the place of the existence helps one to understand the reasons of the variability of the species composition in a fragmented environment (Baselga, 2007, 2010). It has been determined that in the high latitudes, $\beta$-diversity is the result of the extinctions of the species in the past and the recent recolonization (Dobrovolski et al., 2012). The spatial rotation of the species makes a significant contribution to the $\beta$-diversity of the grouping of birds ( $\mathrm{Si}$ et al., 2015). The estimate of $\beta$-diversity can help to understand the complex environmental processes, which will promote the development of strategies of the nature conservation (Kreft \& Jetz, 2010; Anderson et al., 2011; Holt et al., 2013; Socolar et al., 2016; Li et al., 2019).

Animals choose the place of the residence depending on the structure of the habitat. In particular, the grouping of the species depends on the fragmentation and the degradation of the habitats (Watson et al., 2004). Ecologically demanding species avoid small areas, while the generalists usually choose the habitats of different sizes (Edenius \& Sjoberg, 1997). The diversity of the grouping of the birds and the density of their population are usually greater in natural forests than in artificial timber plantations (Saniga, 1995) and it depends on the complexity of the projective vegetation cover (Willson, 1974). In anthropogenically transformed environments, the diversity of the vertebrates, both at the species level and at the level of the grouping, is determined by the area of certain vegetation cover and the complexity of the landscape (Herrera et al., 2016). The edaphic and the plant factors affect the stability of the grouping (Zhukov et al., 2019). The groupings of birds are more affected by the dynamics of the vegetation structure than by climatic change (Zellweger et al., 2017).

In recent decades, interest in the reaction of the birds to the warming of the climate has increased (Wormworth \& Mallon, 2006). The climatic change affects birds in the same way as the climate affects them in general (Jiguet et al., 2010). The reaction of birds to the climate is determined by their tolerance to the temperatures (Bryan \& Bryant, 1999; Pendlebury et al., 2004; Jiguet et al., 2010); by the predominant habitats, the dynamics of the food base, the area size (Bohning-Gaese \& Lemoine, 2004; Cardillo et al., 2005; Jetz et al., 2007); by phenology, the distribution, the fertility and the duration of the reproduction period (Cardillo et al. 2005; Jiguet et al., 2006; Brommer, 2008).

The researches on the groupings of the birds in the South of Ukraine have been devoted to the detection of: their differences in the natural and the anthropogenic landscapes (Koshelev, 2018; Ayubova \& Koshelev, 2019); the search for the patterns of the dynamics of the diversity of the groupings of the birds depending on the landscape diversity and the area of the territory of the biotopes (Koshelev et al., 2019); the definition of the peculiarities of the distribution of the grouping of the birds in different wetlands by the place of their feeding (Andruyshchenko \& Zhukov, 2016); the perspectives of the protection of the reed ornithocomplexes depending on their structure and the dynamics (Koshelev, 2017).

Naturally, in any classification, a considerable number of the species occupies the intermediate position and their attribution to a certain ecological group is often arbitrary, and the boundaries between these groups are not clear and sufficiently conditional. Moreover, the biomorphic specialization of many birds varies depending on the season and the location, and also differs in the different parts of their ranges and even in the different biotopes (Ponomarenko, 2004). Therefore, without taking into account the regional peculiarities, a lot of the classifications are purely theoretical and they do not allow one to single out the list of the habitats which corresponds to the needs of the birds from the different ornithofaunistic complexes, and the absence of which make impossible the existence of native birds in a certain region, especially the rare species. That is why in this work an attempt has been made to determine the species and the topical composition of native ornithofaunistic complexes of the dry-steppe zone of Ukraine by means of the combination of faunistic (ornithofaunistic complexes) and ecological (topomorphs). The proposed classification is aimed not at the description of the structure of fauna and the population of the birds of the researched region, but at the apportionment of the main characteristics of the habitats which determine the changes in the areas and the numbers of native birds, especially those which belong to the category of the endangered species. The definition of the fauna-topomorphic composition of the native (autochthonous) grouping of the birds as the nucleus of the regional avifauna, actualizes the priority of the preservation or the reproduction of the habitats which are necessary for the protection of native birds, but not widespread species, synanthropes, invasive species or species diversity in general, especially in the protected natural territories (Andryushchenko, 2017).

The aim of the research presented here is to ground the faunatopomorphic classification of the birds of the zone of dry steppe of Ukraine by the place of their predominant feeding, nesting and resting, and to determine the taxonomic and the ecological composition of native ornithofaunistic complexes of this region by this classification.

\section{The brief characteristics of the zone of dry steppe of Ukraine}

In Eurasia, the landscape zone of the dry steppes stretches from the northern Black Sea coast to Mongolia and China (Milkov, 1956; Perelman, 1975; Pashchenko, 1999). Within Ukraine (Fig. 1), there is the western enclave of this zone, which is surrounded by other landscape zones and regions (Krivulchenko, 2005; Andryushchenko \& Vorovka, 2016). According to the climatic indicators, this enclave has the lowest continentality for all the dry steppe zone (Dobrovolskyi, 2014), which promotes the formation of the original population of the birds, not only during the nesting period, but also during the year. But its avifauna, as an integral natural region, has hardly been researched (Andryushchenko \& Diadicheva, 2019).

The specifics of the primary landscape structure of the zone of dry steppe of Ukraine is the alternation of mostly open territories and the river valleys, which mostly near-latitudinally (and in the Crimea and latitudinally) separate them, and also the presence of the large wetlands such as sea gulf, estuaries, salt lakes with numerous salt-marshes, the islands and the peninsulas. Along the lines of the contact between them there are transitional strips of coastal cliffs and lowland shores with woody and shrubby vegetation, meadows, etc. Accordingly, the steppe species dominate in the open areas, the marine species dominate in the water bodies, and the 
steppe and the coastal species dominate in the transition zones. The steppe species regularly fly to the watering places, and in the dry periods move on a massive scale to the coast with the more stable forage base. Instead, most coastal birds regularly explore territories far beyond wetlands (up to dozens of kilometers) in search of the food, and some species even nest at a distance from the water bodies (for example, Tadorna ferruginea, T. tadorna)

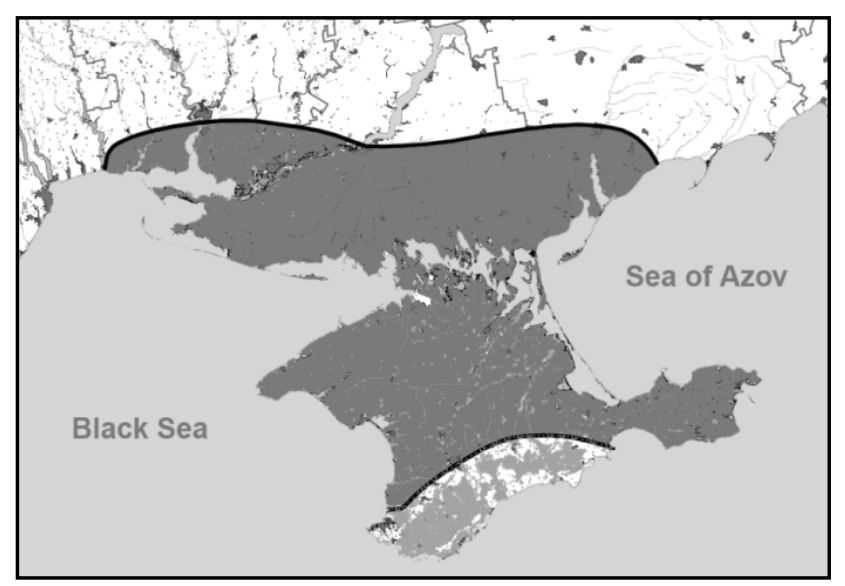

Fig. 1. Zone of dry steppes within Ukraine

During the last century, the landscape structure of the region has been simplified with the anthropogenic transformations, mainly with the creation of the network of woodland belts, irrigation canals, ponds and settlements (Andryushchenko \& Vorovka, 2016). These artificial ecotones have promoted the resettlement of forest and river species in the region, and also the birds of the cliffs and the settlements.

\section{The grounding of fauna-topomorphic classification} of autochtonous birds

In view of the high mobility of birds, which allows them to inspect during the day large territories with a very diverse set of the habitats, often highly ecologically contrasting (some are nesting sites, some are resting sites, others are feeding sites), in faunistic and zoogeographical research their grouping is traditionally associated with a certain landscape, and within it is associated with single habitats or several habitats. In turn, the landscape is a natural geographical complex in which all the main components (relief, climate, water, soil, vegetation and fauna) are in complex interaction and interdependence, forming a single inseparable system which is similar in the condition of its development (Gentilli, 1968; Reimers, 1990; Dranga et al., 2016; Chaplygina et al., 2018). According to Directive 2009/147 / EC of the European Parliament and of the Council of 30 November 2009 on the conservation of wild birds (http://data.europa. eu/eli/dir/2009/147/oj), a habitat is an environment in which, due to certain abiotic and biotic factors, certain species exist at any stage of their life cycle (nesting, nomading, migration, wintering). The peculiarities of the landscape components determine the diversity of ornitho-complexes (MacArthur \& MacArthur, 1961). The composition of plant grouping (Hulbert, 2004), the spatial heterogeneity and the complexity of the habitats (Roth, 1976; Cousin \& Phillips, 2008) and the degree of their transformations are determinative in the terrestrial habitats (Karp et al., 2018). Birds are vertebrates with a large amount of tolerance to the conditions of the environment and, therefore, they react to the changes of the state of habitats, not so much through change of the species composition as through change in their numbers and activity (Ponomarenko, 2004).

The structural properties of the habitats and, so, their correspondence to the requirements of individual species of bird or certain grouping of birds can be changed with the diverse factors, including pasture (Williams, 1990; Ammon \& Stacey, 1997; Ludwig et al., 2000), fires (Coops \& Catling, 2000) and logging (Willett, 2001). It has been proved that the reaction of groupings of birds to agro-technical measures depends on the climatic conditions. For example, in agricultural landscapes, the group of birds in the gradient of the amount of rainfall contains more xerophilous species than hygrophilous species (Karp et al., 2018). Such information makes it possible to form more exact characteristics of the habitats of endangered species and to predict the potential consequences for them from the changes of environment caused by different types of land use (Cousin \& Phillips, 2008), in particular, the species richness and the alignment of the grouping of the birds (Kricher, 1972).

Voinstvensky (1960) singled out 5 ornithofaunistic complexes for the steppe zone of Europe according to the belonging of the species to the historically formed fauna and the corresponding coincidence of their nesting areas with the certain landscape and zoogeographical regions: the 3 main zonal ornithofaunistic complexes are "steppe", "forest", "waterloving"; the 1 intermediate complex (spatially narrowly-localized, usually between "steppe" and "water-loving") is "birds of coastal cliffs and ravines" and the 1 synanthropic complex (situational combination of the representatives of all mentioned complexes and invasive species) is "birds of settlements". In turn, the steppe ornitho-faunistic complex is divided into the birds of "dry steppes" and "dampish steppes", the forest complex is divided into birds of "wood plantations" and "forest edge and shrubs", and the water-loving complex is divided into birds of "river valleys of northern origin", "river valleys of southern origin" and "sea coasts, islands, salt lakes, estuaries". It is proposed to treat the species of the last of mentioned water-loving ornitho-complexes Lugovoi (2007) as autochtonous representatives of the so-called "coastal-island landscape zone of the southern seas of the medial part of the Palearctic".

Belik (1992), pointing out that, unlike plants, animals depend mainly on the trophic and the protective conditions, divided the birds by ecological groups, mainly by their nesting place: dendrophils, which nest mainly among woody-shrub vegetation; campophils which nest and feed in the open grass landscapes; sclerophils, which require erosive cavities in the geological rocks or their analogues for nesting; limnophils, which are ecologically associated mainly with shoal and near-water biotopes; hydrophils, which spend their lives mainly in deep sea and only for reproduction go ashore. But, for some reason, in this classification, the feeding place with the certain exceptions, practically coincides with the nesting place, except for sclerophils and dendrophils, which obtain their food not only in the nesting places, but also in the air or in the open landscapes. Although, it is well known that most species of the birds often, or even mainly, feed not in the places of the location of the nests (for example, nesting in woody-shrubs thickets and feeding at ponds or in steppe areas; nesting in water bodies (on water, aquatic vegetation, dampish soil), and feeding in steppe areas and agricultural fields or in the air, etc.).

Koshelev \& Pakhomov (2020) highlighted the ecologo-biotope ornithocomplexes such as aquatic (floodplain, plant systems, lakes and ponds, riverbeds), overland, terrestrial (meadow, residential, agricultural, steppe, salt, urbanized, forest) and island (mainland and muddy). But, in the absence of the lists of the species of the offered ornithological complexes in the given work, it is not clear by what criteria and how they are distributed among mentioned groups. Also, it is unclear which species belong to the island ornithocomplexes, if there are solonchaks, meadows and steppes on many islands, and which to the floodplains are, if in the floodplains there are meadows, steppes, oxbow lakes, including those with islands. In another work (Koshelev et al., 2019) it is unclear by what features the types of biotopes are distinguished and on what principle the species of the birds are distributed according to them (whether by nesting place, by number of individuals, by frequency of occurrence, etc.). In particular, the most common biotope by area and the contrastingly fragmented by character is agricultural landscapes, for some reason, incorrectly united into agrocenosis (obviously by origin, predominance of monocultures and use by humans). But for most birds, at least the steppe species, it is not the agricultural activities and the purpose of the land use which are the determinative, but rather the presence and the accessibility of food, the places which are suitable for nest building and safe incubation of the eggs, the protective and the comfortable conditions for the rest are determinative (Andryushchenko, 2006). Although the agricultural activities affect the feeding, the nesting and the rest of the birds (negatively, positively or neutrally), it is not the determinative factor for the species which are able to settle equally on ploughed lands and as in the natural habitats. Therefore, for feeding, nesting and resting, different species choose places with a certain height, density and mosaic of herbaceous vegetation, both in agricultural fields and in natural habitats (Andryushchenko, 2006). According to these indi- 
cators, and not only according to the species composition of the crops and the weeds, the agricultural lands (or so-called agrocenosis) differ significantly from each other as from fallow land without vegetation to fallows with dense tall vegetation. And according to the state of the development/ transformation of the vegetation (sowing, sprouting, mature plants, stubble, etc.) and the character of the use (without watering, irrigation, fallow land, rice paddies, etc.), they are more contrasting than salt-marshes, meadows and steppes. The estimate of the complexity of the structure of the habitat as the condition for the existence of individual species will provide further understanding of the reason for the change of their numbers (Ford et al., 2001). The fragmentation and the degradation of the place of the residence affect the state of the grouping of the birds (Watson et al., 2004) regardless of their genesis and the character of the economic use and, therefore, agricultural land should be considered as the place of feeding, nesting and resting of birds along with the natural landscapes or the habitats.

The evolution of birds has followed mainly the way of wide adaptive radiation and it has contributed to the ecological diversity of species, and therefore, birds have been able to settle almost all biotopes of the Earth not in single species but in diverse complexes (Poznanin, 1988). Considering that birds belong to animals with a developed higher nervous activity, which provides them with effective interaction with the environment, the distribution of species by different landscapes, on the level of their environmental needs, also determines the peculiarities of their behaviour: courtship, territorial conflicts, incubation of eggs, taking care of chicks, the protection of offspring, the reaction to humans, etc. Most of these behavioural activities are individual, acquired in ontogenesis by means of teaching, and, to extent, to adjust (to correct) the ecological needs of the birds, and often even can be determinative during the choice of the place in the physical space (in the landscape) for the realization of the main life functions such as feeding, resting (recovery, hiding from enemies, minimization of the impact of the negative weather conditions, plumage care, etc.) and reproduction (the search of a sexual partner, choice of a nesting territory and its protection, incubation of eggs, taking care of chicks, feeding, protecting). So, the classifications of the grouping of the birds should be based not only on their faunistic and the ecological (topical) needs, but also take into account the ethological (behavioural) peculiarities of the individual species.

Unlike ecologists, who consider the positioning of animal species in the ecological space for the assignment of the advantage of the certain horizontal tier of the biogeoceonosis and ways of movement (Akimov, 1954; Zhukov, 2009), ornithologists, at least faunists and zoogeographers, often consider birds within the perspective of physical space. Therefore, for them, following the birds, the physical (mechanical) properties of the landscape and its components are the priority, but not the chemical, thermal, biocoenotic properties and so on. Accordingly, for most of them, at least in the dry steppe zone of Ukraine, the leading principle is not the species composition of the vegetation, but its height, the projective cover area, tiers, mosaics, not soil fertility, and its mechanical composition such as clay, sand, stony or solid rocks, etc. In addition, as a rule, the genesis of the landscape and its components (anthropogenic or natural) are not determinative for the birds, but their state (the degree of the transformation in the anthropogenic habitats or the phase of succession in natural habitats). Thus, the steppe birds, in particular, Anthropoides virgo, Otis tarda and Burhinus oedicnemus, by the presence of short rarefied grass, nest in habitats diverse by origin and degree of transformation such as natural (virgin steppes), natural-anthropogenic (pastures as steppes, partially converted by cattle grazing) and anthropogenic (agricultural fields) (Andryushchenko, 2006, 2007). Even among agricultural lands diverse by the degree of transformation, these birds prefer for the nesting areas with short sparse vegetation, which does not prevent them from freely overlooking the surrounding territory (to observe the actions of their partners, competitors, people, predators, etc.) and moving freely to gather food and take care of chicks (Andryushchenko, 2018).

As noted, birds choose certain habitats based on the location (location) of nests in physical space, as well as the availability of places to feed (to restore energy consumption) and places to rest (to save energy) (Hilden, 1965; Thomas et al., 1979; Ilyichev et al., 1982; Belik, 1992). Given that the birds feed all their lives, and the nesting period in the researched region is only one to three months a year and they do not nest every year, it is more logical that the place of the feeding is the priority. Besides, the priority of the nesting does not help in determining the ecological nature of the birds in the post-nesting period, the migration and wintering period. During these periods of the annual cycle for the birds, along with the place of the feeding, the existence of protective conditions such as the places for day or night rest is also of priority. So, obviously, the attribution of each species to any eco-group (topomorphs) should be guided by the scheme: firstly, the place of the feeding of the birds, and only then the place of their nesting (for nesting individuals) or the place of resting (for non-nesting individuals). The difficulties of the classification are caused not only by the absence of clear boundaries between the position of the species in the physical and the ecological space, but also by the constant changes in the space (environment) and the ability of the birds to adapt quickly (accommodate) to these changes, not only during one or more generations but also during the lifetime of an individual (ontogenesis). And given that in different regions, the nature, the tempo, the scale of the change do not coincide, correspondingly, different regional peculiarities of the adaptation to them are produced in the birds of the same species. Therefore, the same species in different landscape zones or in the same place but in different transformed conditions, can belong to the different ecological (topomorphic) groups. For example, by the nesting place, Corvus monedula in the mountains is a sclerophil (ornithofaunistic complex of cliffs), and on the plain it is synanthropic species (complex of the settlements), Passer montanus in the settlements are predominantly sclerophiles, and outside they are dendrophils, Phalacrocorax carbo on the islands build their nest on the ground, but under the anthropogenic pressure, mostly from fishermen, they begin to nest in trees. Rufibrenta ruficollis in nesting places in the Arctic is a sclerophil which nests on the coastal slopes of the rivers and the lakes, but on its wintering grounds in southern Ukraine this species is hydrophilous and campophilous, feeding mainly on salt meadows and the agricultural fields (Cranswick et al., 2012). Anthropoides virgo during nesting is almost exclusively a campophil, and in the postbreeding, the migration and the winter periods it is mainly a hydrophil, more than $50 \%$ of time of the day is located at shallow water bodies and their shores (Andryushchenko \& Shevtzov, 1998). Therefore, the classifications of the topomorphic groups of the birds are correct only for certain regions and they should be developed for specific use (Root, 1967; DeGraaf, 1985).

Naturally, the diversity of the birds, in particular ecological, cannot be ideally described by any of the existing classifications because many species demonstrate, often at the level of the individual, great flexibility in the choice of the place for the building the nest, resting and foraging (including adoption of new elements of diet and using new methods of obtaining this). Each species of bird occupies a unique position in physical (landscapes) and ecological (habitat or place of the realization of its main activities) space, but for the definition of the general peculiarities of their differentiation in it, especially for the reproduction and the protection of the rare species and groupings, classification is required which is based on clear criteria. Accordingly, the proposed further classification consists of the selection of native ornitho-faunistic complexes of the zone of dry steppes of Ukraine and the differentiation of the birds from their composition by ecological (topomorphic) groups by the place of the predominant feeding-nesting-rest, aimed at the definition of the main requirements of native birds and groupings in terms of the landscapes and the habitats providing support for their existence in the mentioned region.

As has been noted, birds use the landscapes (habitats) for feeding, nesting and resting in different ways. In the process of carrying out their vital functions, these main activities are often combined in different correlation such as during feeding or taking care of chicks, birds can correct their plumage from time to time, while taking care of chicks they can grab food or doze, and during rest they can display temporarily, peck something and so on. So, in the mentioned context, all activities of nesting birds in the place (on substrate) of location of the nest are understood under nesting - with it (during building), on it (incubation of eggs, care for chicks) or near it (resting, courtship, territoriality, etc.). Accordingly, resting consists not only of the complete resting of the birds without any visible movements, but also of the care of the plumage and other comfort behaviour. Feeding includes active search, extraction (grabbing, digging, plucking, etc.) and the absorption of food, which can be temporarily inter- 
rupted by short-term manifestations of other activities. Accordingly, within the certain landscapes (habitats) by the place or the substrate, in/on which mainly the main activities are realized such as feeding, nesting and resting, the birds of the abovementioned ornithofaunistic complexes can be divided into the following topomorphs:

- xerophils (from the ancient Greek xeros - dry) - on the surface of the soil with grass vegetation or without grass, which is not regularly moistened with groundwater;

- edaphils (from the ancient Greek edaphos - soil) - in the soil with different surface slopes (niches, burrows, ledges on slopes, cliffs, rocks or their anthropogenic analogues such as quarries, buildings, towers, pylon and other structures, etc.);

- hygrophils (from the Greek hygros - moisture) - on damp soil of mostly lowland shores of water bodies (beaches, salt-marshes, meadows, etc.) and in the places flooded by soil (depressions with different low relief) or other waters (from artesian wells, irrigation and drainage channels, etc.);
- hydrophils (from the Greek hydor - water) - on/in water, under water (in its thickness or in the soil of the bottom) or on surface of water vegetation;

- dendrophils (from the Greek dendron - tree) - on bushes and trees (or in hollows);

- aerophils (from the Greek aer - air) - species capable of feeding in flight (able to snatch food in the air, including from soil, water, plants, etc.).

So, it is proposed to distribute nesting species of the zone of dry steppe of Ukraine by fauna-topomorphic complexes according to the scheme: ornithofaunistic complex (by the priority landscapes and habitats) feeding place (by priority substrate, mainly on/in which feed is obtained) nesting place (by priority substrate location of nest for the nesting individuals) or resting (by priority substrate, mainly on which non-nesting individuals rest, Fig. 2). The binary definition of the topogroup as "feeding nesting/resting" will be optimal (not overloaded) but given that the nesting and the resting places do not coincide in many species, we are forced to use ternary names as "feeding - nesting - resting".

Fauna-topomorphic complex

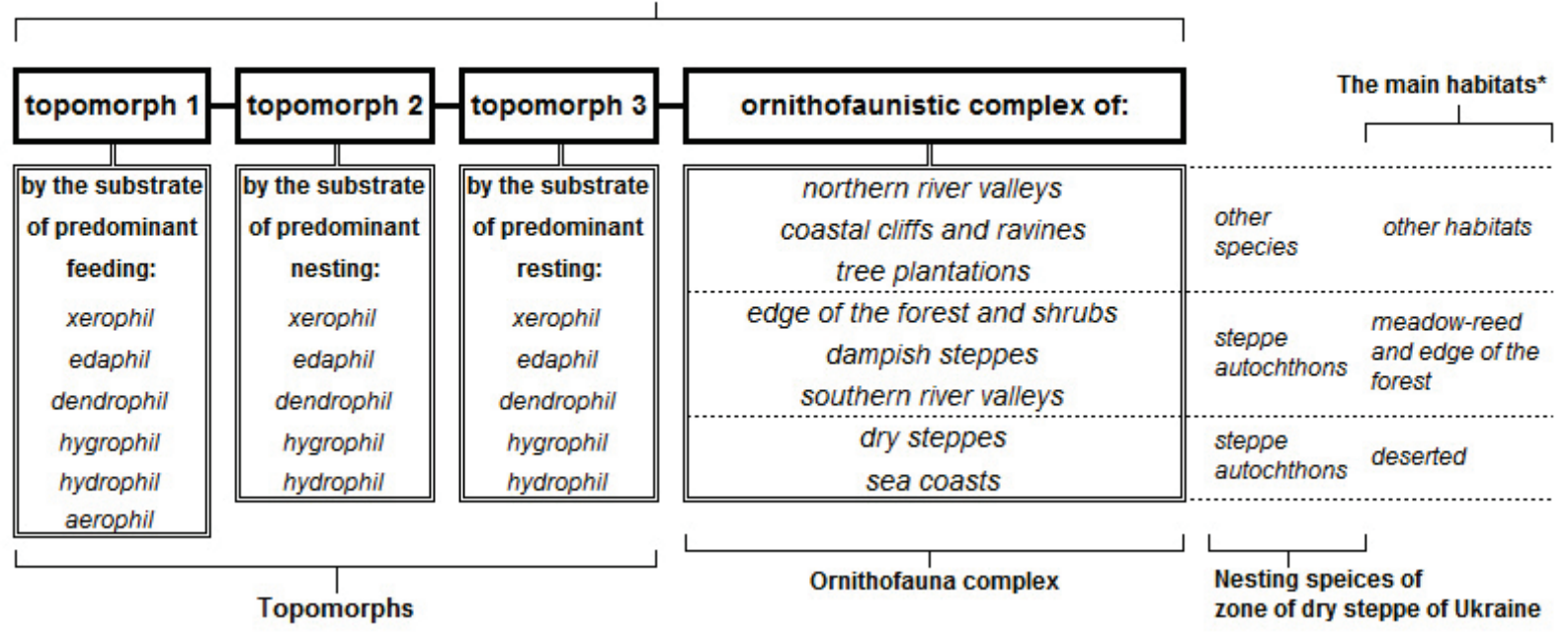

Fig. 2. Scheme and criteria of the distribution of the birds of the zone of dry steppe of Ukraine by fauna-topomorphic complexes:

* - main habitats: "desert" habitats is open territories mostly with the short sparse grass or without any vegetation (dry and desert steppes, mostly stony, salty and sandy, salt-marshes, beaches, small islands, spits and bars, and also agricultural fields with the appropriate vegetation and the degraded pastures); "meadow-reed and edge of forest" habitats are open territories with dense tall herbaceous vegetation (typical and meadow steppes with single trees and shrubs or with it small thickets, including agricultural fields with sparse woodland belts, and along the river valleys there are meadows and reed-swamp thickets with areas of water without surface vegetation); "other habitats" are besides desert, meadow-reed and edge of forest habitats, there are also there are diverse azonal habitats (artificial forests, settlements, zones of stationary recreation, industrial territories, cliffs of ravines, cliffs of the shores of seas, rivers, lakes, or their anthropogenic analogues as quarries, canals, ponds and reservoirs)

\section{Selecting of native ornithofaunistic complexes of the researched region and determination of their taxonomic composition}

Native species and groupings of birds are defined with the classification of the faunistic complexes of the steppe zone of Europe (Voinstvensky, 1960). Considering the other classifications (Shulpin, 1940; Akimov, 1954; Hilden, 1965; Thomas et al., 1979; Ilyichev et al., 1982; Belik, 1992), the mentioned-below ornithofaunistic complexes in the zone of dry steppes of Ukraine can be considered:

- steppe complex - campophilic complex (from the Latin campo plain, open place, field) includes birds that within the researched region tend to inhabit flat terrains which are not regularly moistened with groundwaters, with mostly grass vegetation (living in or on it) or on the territories deprived of any grass, in particular on the agricultural lands, and according to Akimov (1954) are poyophiles or birds of grassy spaces and deserts;

- complex of coastal cliffs and ravines - kremnophilic complex (from the ancient Greek krēmnós - ground) includes birds that tend to inhabit places with predominance of soil surfaces (clay, sand, stony or stone) with the different slopes; to call this sclerophilic (from the Greek scleros solid) is not completely correct because the "hardness" of rocks does not have meaning and most species of the abovementioned complex prefer soft soil, at least those that dig holes (Coracias garrulus, Alcedo atthis, Merops apiaster, Riparia riparia, etc.), especially considering that in the researched region rocky cliffs are not very common;
- forest complex - drymophilic complex (from the ancient Greek drymodes - forest) includes birds that inhabit in thickets of wood-shrubs (between/under or on it) and at least in the dry steppe zone according to Havrielenko \& Lystopadskiy (2012) it consists of "accidental" species (associated with the mentioned vegetation but almost independent of its presence), obligatory dendrophils (all vital functions are associated with trees) and facultative dendrophils (not all vital functions are associated with trees but do not inhabit areas away from trees);

- water-loving complex, or rather a complex of water bodies (because it lives on water bodies with their different shores, and not on water as such) - limnophilic complex (from the ancient Greek limn - water body) includes birds inhabiting wetlands, which consist of natural or artificial, permanent or temporary, standing or flowing, fresh, brackish or salt water bodies, surfaces of sea waters up to $6 \mathrm{~m}$ deep, their islands, shores (land without vegetation or with meadows, steppes, forests, shrubs, in including agricultural) and transition zones (beaches, salt marshes), which are alternately under water or without it, according to the "Convention on wetlands of international importance, especially as a habitat for waterfowl" (www.ramsar.org/sites/default/files/documents/library/current_convention text_e.pdf);

- complex of settlements - synanthropic complex (from the ancient Greek syn - together and anthropos - man) includes birds, that are secondary in the researched region and consists of 9 species of different origin: Passer domesticus is drymophilic, Ciconia ciconia is limnophilic, 
and Athene noctua, Tyto alba, Apus apus, Riparia riparia, Delichon urbica, Corvus monedula, Passer montanus are kremnophilics, so the ecological distribution of these birds should be considered in the composition of mentioned complexes.

181 birds species regularly nest in the zone of dry steppe of Ukraine, from the 333 species which inhabit the abovementioned region in the different periods of the annual cycle (Andryushchenko \& Diadicheva, 2020). From the list of Voinstvensky (1960) in the researched region 5 species can nest also (Crex crex, Locustella fluviatilis, Acrocephalus palustris, Phylloscopus trochilus, Aegithalos caudatus), and 37 species no longer nest in it now (Podiceps auritus, Aythya fuligula, Pernis apivorus, Pandion haliaetus, Milvus milvus, Circus cyaneus, C. macrourus, Accipiter nisus, Accipiter brevipes, Circaetus gallicus, Hieraaetus pennatus, Aquila rapax, A. clanga, A. pomarina, Falco naumanni, Grus grus, Porzana pusilla, Tringa ochropus, T. stagnatilis, Limosa limosa, Larus canus, Columba oenas, Bubo bubo, Picus viridis, Dendrocopos leucotos, D. minor, D. medius, Lanius excubitor, Troglodytes troglodytes, Locustella naevia, Acrocephalus dumetorum, Acrocephalus paludicola, Hippolais caligata, Ficedula hypoleuca, Ficedula parva, Monticola saxatilis and Turdus viscivorus). Relatively recently, Saxicola maurus has appeared here, represented by the subspecies variegatus. Motacilla feldegg has been added to the list of nesting species, having previously been considered as a subspecies of M. flava and therefore it has been absent from the species composition of the steppe ornithofaunistic complex (Voinstvensky, 1960).

According to the given scheme (Fig. 2), in the researched region 33 dry steppe species (which is $18.3 \%$ of all nesting species of the region) can be considered as native birds, of which 18 belong to the ornithofaunistic complex of the dry steppes, and 15 belong to the complex of sea coasts (Table 1). In particular, dry-steppe autochthons are 1 Falconiformes $(\mathrm{Bu}$ teo rufinus), 1 Galliformes (Perdix perdix), 4 Gruiformes (Anthropoides virgo, Otis tarda, Tetrax tetrax, Burhinus oedicnemus), 1 Charadriiformes (Glareola nordmanni), 11 Passeriformes, of which they are 4 Larks ( $G a-$ lerida cristata, Calandrella cinerea, C. rufescens, Melanocorypha calandra), 1 Pipit (Anthus campestris), 2 Chats (Saxicola rubetra, S. torquata), 2 Wheatears (Oenanthe oenanthe, O. isabellina) and 1 Bunting (Emberiza melanocephala), and also 1 Wagtail (Motacilla feldegg), which was not previously allocated to the individual species and, therefore, it was not listed by Voinstvensky (1960). And sea autochthons are represented by 1 Pelecaniformes (Phalacrocorax aristotelis), 1 Ciconiiformes (Phoenicopterus roseus), 3 Anseriformes (Tadorna ferruginea, T. tadorna, Mergus serrator) and 10 Charadriiformes, of which are 2 Waders (Charadrius alexandrinus, Recurvirostra avosetta), and 5 Gulls (Larus ichthyaetus, L. melanocephalus, L. genei, L. cachinnans, L. michahellis) and 3 Terns (Gelochelidon nilotica, Hydroprogne caspia, Thalasseus sandvicensis). The abovementioned dry-steppe native birds mainly inhabit the open territories without grass vegetation or with short rarefied grass cover such as dry and deserted steppes (mostly rocky, salty or sandy), salt marshes, beaches, small islands, bars and spits, and also agricultural fields with appropriate vegetation and on meadows and steppes with the moderate grazing load.

54 species (29.8\% of all nesting species) from composition of 3 ornithofaunaistic complexes belong to the steppe autochthons of the zone of dry steppe of Ukraine: 6 species of dampish steppes, 14 species of edge of the forest and shrubs and 34 river species of southern origin (Table 2). Natives of the dampish steppes are 1 Falconiformes (Circus pygargus), 1 Galliformes (Coturnix coturnix), 1 Strigiformes (Asio flammeus) and 3 Passeriformes (Alauda arvensis, Emberiza calandra, E. hortulana). 1 Galliformes (Phasianus colchicus) and 13 Passeriformes (Lullula arborea, Anthus trivialis, Lanius collurio, Sylvia nisoria, S. borin, S. communis, S. curruca, Erithacus rubecula, Luscinia megarhynchos, L. luscinia, Passer domesticus, Acanthis cannabina, Emberiza citronella) belong to natives of the edge of the forest and shrubs. The river natives are 2 Podicipediformes (Tachybaptus ruficollis, Podiceps nigricollis), 4 Pelecaniformes (Pelecanus onocrotalus, P. crispus, P. carbo, P. pygmaeus), 9 Ciconiiformes (Ixobrychus minutus, Nycticorax nycticorax, Ardeola ralloides, Egretta alba, E, garzetta, Ardea purpurea, Platalea leucorodia, Plegadis falcinellus, Ciconia ciconia), 5 Anseriformes (Cygnus olor, Anas strepera, Netta rufina, Aythya nyroca, Oxyura leucocephala), 5 Gruiformes (Rallus aquaticus, Porzana porzana, P. parva, Gallinula chloropus, Fulica atra), 4 Charadriiformes (Himantopus himantopus, Glareola pratincola, Chlidonias leucopterus, C. hybrida) and 5 Passeriformes (Locustella luscinioides, Acrocephalus agricola, A. scirpaceus, A. arundinaceus, Panurus biarmicus).

\section{Table 1}

Distribution of nesting species of the zone of dry steppe of Ukraine by ornithofaunistic complexes

\begin{tabular}{cccccc}
\hline \multirow{2}{*}{ Ornithofaunistic complexes } & \multicolumn{4}{c}{ Number of nesting species } \\
\cline { 2 - 6 } & $\begin{array}{c}\text { dry steppe } \\
\text { autochthons }\end{array}$ & $\begin{array}{c}\text { steppe } \\
\text { autochthons }\end{array}$ & $\begin{array}{c}\text { oth- } \\
\text { ers }\end{array}$ & $\begin{array}{c}\text { all } \\
\text { types }\end{array}$ \\
\hline \multirow{2}{*}{ Drymophilic tree plantations } & 0 & 0 & 49 & 49 \\
& edge of the forest \& shrubs & 0 & 14 & 0 & 14 \\
\hline \multirow{2}{*}{ Campophilic dampish steppes } & 0 & 6 & 0 & 6 \\
& dry steppes & 18 & 0 & 0 & 18 \\
\hline \multirow{2}{*}{ Limnophilic } & sea coasts & 15 & 0 & 0 & 15 \\
& nouthern river valleys & 0 & 34 & 0 & 34 \\
\hline Siliceous & coastal cliffs \& ravines & 0 & 0 & 28 & 28 \\
\hline & Total: & 0 & 0 & 17 & 17 \\
\hline
\end{tabular}

Dry-steppe and steppe autochthons together with the representatives of other ornithofaunistic complexes such as tree plantations, river valleys of the northern origin, coastal cliffs and ravines form the nesting avifauna of the zone of dry steppe of Ukraine (Table 1). Dry-steppe and steppe autochthons form only $48.1 \%$ of all species of the birds which regularly nest in mentioned region. All representatives of the nesting ornithofauna, depending on the topomorphic preferences, are divided into zonal (sea, steppe or agricultural analogues), intrazonal (river floodplains), azonal (artificial forests, settlements, zones of the stationary recreation, industrial territories, etc.) landscapes and transitional strips such as the edge of the forest and the woodland belts (as anthropogenic analogues of forest edge), steep slopes and shoreline cliffs, ravines, depressions, river valleys and lakes (or their anthropogenic analogues such as canals, ponds, reservoirs, quarries).

\section{The determination of the ecological composition of the native ornithofaunistic complexes in the researched region}

Taking into account the abovementioned and in accordance with the proposed scheme (Fig. 2) dry-steppe autochthons by the places (by the substrate) of the priority implementation of the main activities such as feeding, nesting, rest, are mainly xerophils $-54.6 \%$ of species (most of which are strict xerophils $-18.2 \%$, xero-hygrophils $-15.2 \%$ and xero-dendrophils $-12.1 \%$, Table 2). Almost equally of dry-steppe autochthons are predominantly hygrophils $-24.2 \%$ (of which a lot of hygro-xero-hydrophils $-9.1 \%$ ) and hydrophils $-21.2 \%$ (the majority hydro-hygrophils $18.2 \%$ ). So, according to the mentioned fauna-topomorphic division, for example, Tadorna ferruginea is a xero-hygro-edaphil of sea coasts, Melanocorypha calandra is a xerophil of dry steppes, Emberiza melanocephala is a xero-dendrophil of dry steppes, Larus cachinnans is a hydro-hygrophil of sea coasts, Tadorna tadorna is a hydro-eda-hygrophil of sea coasts.

In contrast to dry-steppe autochthons, steppe autochthons gravitate towards the open territories with predominance of the developed grass such as steppes and meadows with the scattered trees and the shrubs or small thickets (including woodland belts) or without them along the shores of water bodies. According to the distribution of topomorphs, like dry-steppe birds (Table 2), in the composition of steppe autochthons, besides the predominant xerophils (39.1\%) and hydrophils (43.7\%), and also a few hygrophils (12.6\%), there are the typical dendrophils (4.6\%) such as Sylvia nisoria, S. borin, S. communis, S. curruca (Table 3).

In conditions of the intensive exploitation of soil and natural grass vegetation, mainly due to plant growing and cattle grazing, the most vulnerable among the native birds in the researched region are xerophils and hygrophils, which realize their main activities on the surface of dry or dampish ground. Xerophils form the majority among dry steppe native birds ( $54.6 \%$ of species), and together with hygrophils ( $21.2 \%$ of species) they form more than three quarters ( $75.8 \%$ of species). 
Table 2

Distribution of dry-steppe native birds of the zone of dry steppe of Ukraine by fauna-topomorphic complexes

\begin{tabular}{|c|c|c|c|c|c|c|c|c|c|c|c|c|c|c|c|c|c|c|c|c|}
\hline \multirow[b]{3}{*}{ Species $* * * *$} & \multirow[b]{3}{*}{ 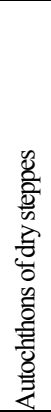 } & & \multicolumn{16}{|c|}{ Priority* place/ substrate of the implementation of basic activities** } & \multirow{2}{*}{\multicolumn{2}{|c|}{ Topomorphs }} \\
\hline & & \multicolumn{7}{|c|}{ Feeding $(6)$} & \multicolumn{5}{|c|}{ Nesting*** $(5)$} & \multicolumn{5}{|c|}{ Rest (5) } & & \\
\hline & & 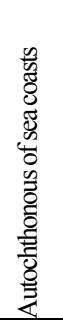 & 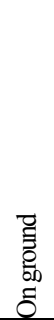 & 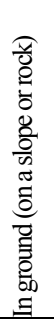 & 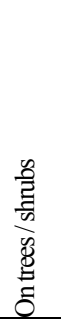 & 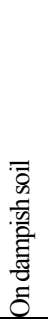 & 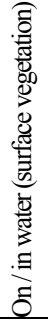 & 駡 & $\begin{array}{l} \\
\overline{0} \\
\overline{0} \\
\overline{0} \\
\tilde{0}\end{array}$ & 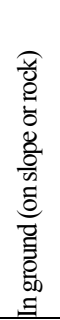 & 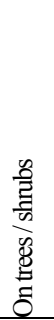 & 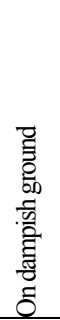 & 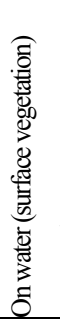 & $\begin{array}{l} \\
\bar{\Xi} \\
\overline{0} \\
\stackrel{0}{0} \\
\Xi\end{array}$ & 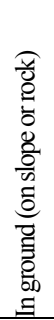 & 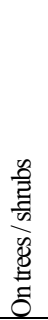 & 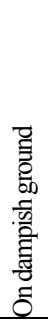 & 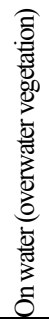 & $\begin{array}{c}\text { by the substrate } \\
\text { of feeding-nesting-resting }\end{array}$ & 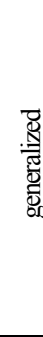 \\
\hline Tadorna ferruginea & - & + & 2 & 0 & 0 & 2 & 1 & 0 & 0 & 5 & 0 & 0 & 0 & 0 & 0 & 0 & 0 & 0 & \multirow[t]{3}{*}{ xero-hygro-edaphil } & \multirow{18}{*}{$\begin{array}{l}\frac{n}{7} \\
\bar{z} \\
\overline{2} \\
x\end{array}$} \\
\hline Anthropoides virgo & + & - & 4 & 0 & 0 & 2 & 0 & 0 & 4 & 0 & 0 & 1 & 0 & 4 & 0 & 0 & 1 & 0 & & \\
\hline Otis tarda & + & - & 4 & 0 & 0 & 2 & 0 & 0 & 4 & 0 & 0 & 1 & 0 & 4 & 0 & 0 & 1 & 0 & & \\
\hline Burhinus oedicneтus & + & - & 4 & 0 & 0 & 2 & 0 & 0 & 4 & 0 & 0 & 1 & 0 & 4 & 0 & 0 & 1 & 0 & xero-hygrophil & \\
\hline Calandrella rufescens & + & - & 4 & 0 & 0 & 2 & 0 & 0 & 3 & 0 & 0 & 2 & 0 & 3 & 0 & 0 & 2 & 0 & & \\
\hline Motacilla feldegg & + & - & 3 & 0 & 0 & 3 & 0 & 0 & 3 & 0 & 0 & 2 & 0 & 3 & 0 & 0 & 2 & 0 & & \\
\hline Buteo rufinus & + & - & 6 & 0 & 0 & 0 & 0 & 0 & 1 & 0 & 0 & 0 & 0 & 1 & 0 & 4 & 0 & 0 & & \\
\hline Saxicola rubetra & + & - & 5 & 0 & 0 & 1 & 0 & 0 & 3 & 0 & 2 & 0 & 0 & 3 & 0 & 2 & 0 & 0 & & \\
\hline Saxicola torquata & + & - & 5 & 0 & 0 & 1 & 0 & 0 & 3 & 0 & 2 & 0 & 0 & 3 & 0 & 2 & 0 & 0 & xero-dendrophil & \\
\hline Emberiza melanocephala & + & - & 6 & 0 & 0 & 0 & 0 & 0 & 0 & 0 & 5 & 0 & 0 & 0 & 0 & 5 & 0 & 0 & & \\
\hline Oenanthe oenanthe & + & - & 4 & 2 & 0 & 0 & 0 & 0 & 0 & 5 & 0 & 0 & 0 & 3 & 2 & 0 & 0 & 0 & \multirow{2}{*}{ xero-edaphil } & \\
\hline Oenanthe isabellina & + & - & 6 & 0 & 0 & 0 & 0 & 0 & 0 & 5 & 0 & 0 & 0 & 5 & 0 & 0 & 0 & 0 & & \\
\hline Perdixperdix & + & - & 6 & 0 & 0 & 0 & 0 & 0 & 5 & 0 & 0 & 0 & 0 & 5 & 0 & 0 & 0 & 0 & & \\
\hline Tetrax tetrax & + & - & 6 & 0 & 0 & 0 & 0 & 0 & 5 & 0 & 0 & 0 & 0 & 5 & 0 & 0 & 0 & 0 & \multirow{5}{*}{ xerophil } & \\
\hline Galerida cristata & + & - & 6 & 0 & 0 & 0 & 0 & 0 & 5 & 0 & 0 & 0 & 0 & 5 & 0 & 0 & 0 & 0 & & \\
\hline Calandrella cinerea & + & - & 6 & 0 & 0 & 0 & 0 & 0 & 5 & 0 & 0 & 0 & 0 & 5 & 0 & 0 & 0 & 0 & & \\
\hline Melanocorypha calandra & + & - & 6 & 0 & 0 & 0 & 0 & 0 & 5 & 0 & 0 & 0 & 0 & 5 & 0 & 0 & 0 & 0 & & \\
\hline Anthus campestris & + & - & 6 & 0 & 0 & 0 & 0 & 0 & 5 & 0 & 0 & 0 & 0 & 5 & 0 & 0 & 0 & 0 & & \\
\hline Larus michahellis & - & + & 2 & 0 & 0 & 2 & 2 & 0 & 0 & 5 & 0 & 0 & 0 & 0 & 2 & 0 & 1 & 2 & hygro-hydro-edaphil & \multirow{7}{*}{ 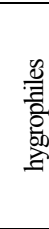 } \\
\hline Larus cachinnans & - & + & 2 & 0 & 0 & 2 & 2 & 0 & 1 & 0 & 0 & 4 & 0 & 0 & 0 & 0 & 3 & 2 & hygro-hydrophilic & \\
\hline Larus melanocephalus & - & + & 2 & 0 & 0 & 2 & 2 & 0 & 1 & 0 & 0 & 5 & 0 & 0 & 0 & 0 & 3 & 2 & & \\
\hline Gelochelidon nilotica & - & + & 2 & 0 & 0 & 2 & 1 & 1 & 0 & 0 & 0 & 5 & 0 & 0 & 0 & 0 & 3 & 2 & hygro-xero-hydrophilic & \\
\hline Thalasseus sandvicensis & - & + & 2 & 0 & 0 & 2 & 1 & 1 & 0 & 0 & 0 & 5 & 0 & 0 & 0 & 0 & 3 & 2 & \multirow{3}{*}{$\begin{array}{l}\text { hygro-xero-aerophile } \\
\text { hygrophile }\end{array}$} & \\
\hline Glareola nordmanni & + & - & 1 & 0 & 0 & 3 & 0 & 2 & 0 & 0 & 0 & 5 & 0 & 2 & 0 & 0 & 3 & 0 & & \\
\hline Charadrius alexandrinus & - & + & 0 & 0 & 0 & 5 & 1 & 0 & 0 & 0 & 0 & 5 & 0 & 0 & 0 & 0 & 4 & 1 & & \\
\hline Phoenicopterus roseus & - & + & 0 & 0 & 0 & 0 & 6 & 0 & 0 & 0 & 0 & 5 & 0 & 0 & 0 & 0 & 1 & 4 & \multirow{8}{*}{ hydro-hygrophil } & \multirow{8}{*}{ 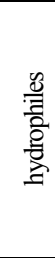 } \\
\hline Mergus serrator & - & + & 0 & 0 & 0 & 0 & 6 & 0 & 0 & 0 & 0 & 5 & 0 & 0 & 0 & 0 & 3 & 2 & & \\
\hline Recurvirostra avosetta & - & + & 0 & 0 & 0 & 0 & 6 & 0 & 0 & 0 & 0 & 5 & 0 & 0 & 0 & 0 & 3 & 2 & & \\
\hline Larus ichthyaetus & - & + & 0 & 0 & 0 & 0 & 6 & 0 & 0 & 0 & 0 & 5 & 0 & 0 & 0 & 0 & 3 & 2 & & \\
\hline Larus genei & - & + & 0 & 0 & 0 & 0 & 6 & 0 & 0 & 0 & 0 & 5 & 0 & 0 & 0 & 0 & 3 & 2 & & \\
\hline Hydroprogne caspia & - & + & 0 & 0 & 0 & 1 & 5 & 0 & 0 & 0 & 0 & 5 & 0 & 0 & 0 & 0 & 3 & 2 & & \\
\hline Tadorna tadorna & - & + & 0 & 0 & 0 & 0 & 6 & 0 & 1 & 4 & 0 & 0 & 0 & 1 & 0 & 0 & 2 & 2 & & \\
\hline Phalacrocorax aristotelis & - & + & 0 & 0 & 0 & 0 & 6 & 0 & 0 & 5 & 0 & 0 & 0 & 0 & 5 & 0 & 0 & 0 & & \\
\hline
\end{tabular}

Note: * - priority - according to the number of the places of the implementation of main activities, from the lowest is " 1 " to the highest is " 5 ", and for feeding is " 6 ", without priority it is " 0 "; ** - place/substrate of implementation of the main activities such as feeding, nesting, resting: on the ground (clay, sand, rocky) and on the short grass vegetation, and also on its anthropogenic analogues (arable land, concrete and other hard surfaces, etc.); in the soil such as holes, niches, voids in the ground with the different incline of the surface, including subvertical (cliffs, rocks, etc.) and in their anthropogenic analogues (buildings, structures, towers, pylons, quarries, etc.); on trees/shrubs they are also on tall grass plants; on damp ground, it is mainly on lowland shores of water bodies (beaches, salt-marshes, meadows, etc.) and in places flooded by ground water (bottoms of diverse depressions and ravines) or other water (from artesian wells, irrigation and drainage channels, etc.); on/in water - on its surface or in the water column, at the bottom, on surface vegetation, in the zone of regular flooding (shoals, beaches, etc.) and on anthropogenic analogues; *** - nesting - is the substrate of the location of the nests (but not courtship, courtship display, care for chicks, etc.); ${ }^{* * * *}$ - species are situated in a systematic order within each generalized topomorph.

Table 3

Distribution of steppe native birds of the zone of dry steppe of Ukraine by fauna-topomorphic complexes

\begin{tabular}{|c|c|c|c|c|c|}
\hline \multirow{2}{*}{$\begin{array}{c}\text { Topomorphs } \\
\text { generalized }\end{array}$} & \multirow{2}{*}{$\begin{array}{l}\text { Topomorphs by place } \\
\text { of feeding-nesting-rest }\end{array}$} & \multicolumn{4}{|c|}{ Number of native species: } \\
\hline & & dampish steppes & edge of the forest and shrubs & river valleys & total \\
\hline Dendrophils & dendrophils & 0 & 4 & 0 & 4 \\
\hline \multirow{6}{*}{ Xerophils } & xero-edo-dendrophils & 0 & 1 & 0 & \multirow{6}{*}{17} \\
\hline & xero-dendrophils & 0 & 9 & 0 & \\
\hline & xero-dendrophils & 2 & 0 & 0 & \\
\hline & xerophils & 3 & 0 & 0 & \\
\hline & xero-hygrophils & 1 & 0 & 0 & \\
\hline & xero-aerophils & 0 & 0 & 1 & \\
\hline \multirow{2}{*}{ Hygrophils } & hygro-hydro-aerophils & 0 & 0 & 2 & \multirow{2}{*}{3} \\
\hline & hygro-hydro-edaphils & 0 & 0 & 1 & \\
\hline \multirow{6}{*}{ Hydrophils } & hydro-hygrophils & 0 & 0 & 7 & \multirow{5}{*}{30} \\
\hline & hydro-hygro-dendrophils & 0 & 0 & 5 & \\
\hline & hydro-dendro-hygrophils & 0 & 0 & 2 & \\
\hline & hydro-dendrophils & 0 & 0 & 7 & \\
\hline & hydrophils & 0 & 0 & 9 & \\
\hline & Total: & 6 & 14 & 34 & 54 \\
\hline
\end{tabular}


At the same time, among the steppe native birds, the majority (55.6\% of species) is formed by predominant hydrophils, but the total share of xerophils (39.1\% of species) and hygrophils (12.6\% of species) is also quite large (51.7\% of species). Also, the xerophils (which form $40.2 \%$ of native species) are represented in five ornthofaunistic complexes (dry steppes, dampish steppes, sea, river and forest), and hygrophils (11.5\% of species) are in three complexes (dry steppes, sea and river), while hydrophils are in two complexes (sea and river), and dendrophils are only in one (the edge of the forest, Fig. 3).

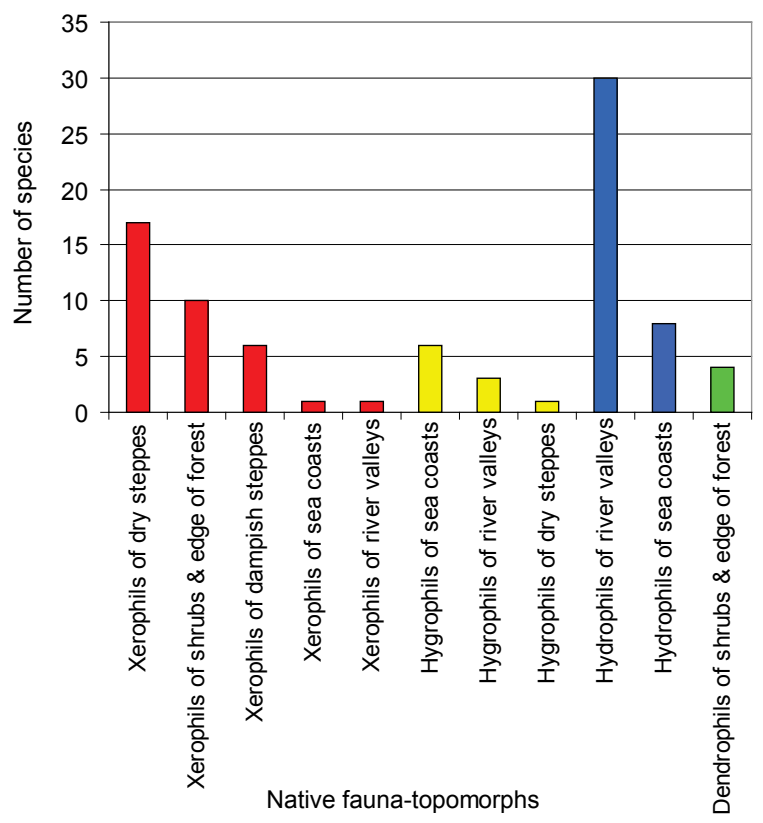

Fig. 3. Quantitative distribution of birds of the zone of the dry steppe of Ukraine by native fauna-topomorphic complexes: xerophils are marked in red, hygrophils are marked in yellow, hydrophils are marked in blue, dendrophils are marked in green

The proposed classification is based on the fact that the different species of the birds or their groupings need such landscapes and habitats in which there are places (substrates) which are together suitable for feeding, for nesting, and for resting. This approach supplements notions about dependence of the grouping of the birds on other characteristics of the habitats, in particular on: their fragmentation and degradation (Watson et al., 2004); the age of the trees or the area of their plots (Hansson, 1994); the origin of the plantations (Saniga, 1995) or area of other habitats (Koshelev et al., 2019); the complexity of the projective cover of the vegetation (Willson, 1974); the structure of reed thickets (Koshelev, 2017); edaphic factors (Zhukov et al., 2017); forage base (Böhning-Gaese \& Lemoine, 2004); depths of water bodies in the place of the feeding (Andryushchenko \& Zhukov, 2016); nature of land use (Jetz et al., 2007); climatic change (Zellweger et al., 2017), mainly temperatures (Bryan \& Bryant, 1999; Pendlebury et al., 2004; Jiguet et al., 2010).

\section{Conclusions}

Native ornithofaunistic complexes in the zone of dry steppe of Ukraine consist of the birds which gravitate towards desert, meadow-reed and marginal-forest habitats. In particular, dry steppe autochthons are campophils of dry steppe and limnophils of sea coast, and steppe autochthons are campophils of dampish steppe, limnophils of river valleys of southern origin, and drymophils of edge of forest and shrub. The mentioned native birds together with drymophils of tree plantations, limnophils of river valleys of northern origin and kremnophils of coastal cliffs and ravines form the nesting avifauna of the dry zone of steppe of Ukraine.

Native ornithofaunistic complexes in the researched region are represented mainly by xerophils (39.1\% of all nesting species) and hydrophils (43.7\% of all nesting species), much less by hygrophils and dendrophils
(12.6\% and 4.6\%, respectively). 29 native birds are included in The Red Book of Ukraine (2009), of which 15 are dry-steppe and 14 are steppe, which are mainly or partially xerophils and hygrophils. It indicates that dry-steppe and sea (especially on salt-marshes) xerophils and hygrophils are in the most vulnerable position. On the agricultural land, they are extremely vulnerable to the intensive exploitation of ground and grass vegetation. In the remnants of the natural areas, in particular in the natural protected areas, most of the representatives of native ornithofaunistic complexes are devoid of habitats which are simultaneously suitable for their feeding, nesting and resting. Native xerophils need open territories with grass vegetation, which do not prevent them from moving freely, searching and obtaining food, taking care of chicks, inspecting the territories (areas of ground without vegetation or with sparse short grass, which is devoid of steppe ground litter); native dendrophils need available places for nesting (single shrubs and trees or their small thickets); native hygrophils and hydrophils need the conditions for nesting, resting and feeding (shallows with surface vegetation, islands, shoals, adjacent meadows and salt-marshes); and most native xerophils and dendrophils also need places for drinking (fresh or slightly saline water bodies).

So, for the preservation of the native birds in the dry-steppe zone of Ukraine, it is necessary to have areas of dry and desert steppes in combination with small wood-shrub thickets, salt-marshes and shallow water bodies with beaches, small islands, bars and spits. The mentioned combinations of the habitats sometimes still occur in the agro-landscape zone of the dry steppe of Ukraine, but they are almost absent in the steppe natural protected areas of the region. Therefore, for the preservation and the protection of the native avifauna, scientifically-grounded biotechnical measures with the restoration of zonal landscapes with the support of the state should be implemented on their territories, which corresponds to the ecological preferences of all the native ornithofaunistic complexes.

\section{References}

Akimov, M. P. (1954). Biomorficheskij metod izucheniya biocenozov [Biomorphic method of teaching biocenoses]. Byulleten Moskovskogo Obschestva Ispytaniya Prirody, 59(3), 27-36 (in Russian).

Ammon, E. M., \& Stacey, P. B. (1997). Avian nest success in relation to past grazing regimes in a montane riparian system. Condor, 99(1), 7-13.

Anderson, M. J., Crist, T. O., Chase, J. M., Vellend, M., Inouye, B. D., Freestone, A. L., Sanders, N. J., Comell, H. V., Comita, L. S., Davies, K. F., Harrison, S. P., Kraft, N. J. B., Stegen, J. C., \& Swenson, N. G. (2011). Navigating the multiple meanings of beta diversity: A roadmap for the practicing ecologist. Ecology Letters, 14, 19-28.

Andryushchenko, A. Y., \& Zhukov, A. V. (2016). Masshtabnyie effektyi v strukture zimuyuschey ekologicheskoy nishi lebedya-shipuna vo vremya zimovki v zalive Sivash [Scale-dependent effects in structure of the wintering ecological niche of the mute swan during wintering in the gulf of Sivash]. Biologicheskiy Vestnik Melitopolskogo Gosudarstvennogo Pedagogicheskogo Universiteta imeni Bogdana Hmelnitskogo, 6(3), 234-247 (in Russian).

Andryushchenko, Y. (2007). The great bustard in Southern Ukraine. Bustard Studies, 6, 111-129.

Andryushchenko, Y. A. (2006). Novye dannye po ekologii zhuravlya-krasavki, drofy i avdotki na yuge Ukrainy [New data of the ecology of the Anthropoides virgo, Otis tarda and Burhinus oedicnemus in the south of Ukraine]. Trudy XII Mezhdunarodnoj ornitologicheskoj konferencii Severnoj Evrazii. Izdatel'stvo SGU, Stavropol'. Pp. 553-572 (in Russian).

Andryushchenko, Y. A. (2018). Preliminary review of co-existence and conflict of cranes and agriculture in Southern Ukraine. In: Austin, J. E., Morrison, K., \& Harris, J. T. (Eds.). Cranes and agriculture: A global guide for sharing the landscape. International Crane Foundation, Baraboo. Pp. 211-218.

Andryushchenko, Y. A., \& Diadicheva, E. A. (2020). Sklad retsentnoi avifauny sukhostepovoi zony Ukrainy [Composition of the recent avifauna of the drysteppe zone of Ukraine]. Berkut, 29, 1-20 (in Ukrainian).

Andryushchenko, Y. A., \& Shevtzov, A. A. (1998). Letnie skopleniya zhuravlyakrasavki na Sivashe [Summer gatherings of Demoiselle crane on Syvash]. Branta, 1, 92-102 (in Russian).

Andryushchenko, Y. A., \& Vorovka, V.P. (2016). Landshaftnyi pidkhid do omitolohichnoho raionuvannia sukhoho Stepu Ukrainy [Landscape development to the ornithological zoning of the dry Steppe of Ukraine]. Visti Biosfernoho Zapovidnyka “Askaniia-Nova”, 18, 79-97 (in Ukrainian).

Ayubova, E. M., \& Koshelev, V. A. (2019). The effect of pyrogenic succession on breeding birds of shelter belts in the north-westem part of the Azov Sea Region. Vestnik Zoologii, 53(2), 149-154. 
Baselga, A. (2007). Disentangling distance decay of similarity from richness gradients: Response to Soininen et al. Ecography, 30, 838-841.

Baselga, A. (2010). Partitioning the turnover and nestedness components of beta diversity. Global Ecology and Biogeography, 19, 134-143

Belik, V. P. (1992). Biotopicheskoe raspredelenie i ekologicheskaya klassifikaciya zhivotnyh [Biotopic distribution and ecological classification of animals]. In: Chteniya pamyati prof. V.V. Stanchinskogo. Izdatel'stvo SGPU, Smolensk. Pp. 13-16 (in Russian).

Belik, V. P. (1992). Podhody i principy regional'nogo faunogeneticheskogo analiza [Approaches and principles of regional fauno-genetic analysis]. Kavkazskij Ornitologicheskij Vestnik, 3, 9-18 (in Russian).

Blake, J. G., \& Loiselle, B. A. (2000). Diversity of birds along an elevational gradient in the Cordillera Central, Costa Rica. The Auk, 117(3), 663-686.

Bohning-Gaese, K., \& Bauer, H. G. (1996). Changes in species abundance, distribution, and diversity in a Central European bird community. Conservation Biology, 10, 175-187.

Brommer, J. E. (2008). Extent of recent polewards range margin shifts in Finnish birds depends on their body mass and feeding ecology. Ornis Fennica, 85, $109-117$.

Bryan, S. M., \& Bryant, D. M. (1999). Heating nest-boxes reveals an energetic constraint on incubation behaviour in great tits, Parus major. Proceedings of the Royal Society of London, 266, 157-162.

Cardillo, M., Mace, G. M., Jones, K. E., Bielby, J., Bininda-Emonds, O. R. P., Sechrest, W, Orme, C. D. L., \& Purvis, A. (2005). Multiple causes of high extinction risk in large mammal species. Science, 309, 1239-1241.

Chaplygina, A. B., Savynska, N. O., \& Brygadyrenko, V. V. (2018). Trophic links of the spotted flycatcher, Muscicapa striata, in transformed forest ecosystems of North-Eastern Ukraine. Baltic Forestry, 24(2), 304-312.

Chemov, Y. I. (2008). Ekologiya i biogeografiya [Ecology and biogeography]. KMK, Moscow (in Russian).

Coops, N. C., \& Catling, P. C. (2000). Estimating forest complexity in relation to time since fire. Austral Ecology, 25, 344-351.

Cousin, J. A., \& Phillips, R. D. (2008). Habitat complexity explains species-specific occupancy but not species richness in a Western Australian woodland. Australian Journal of Zoology, 56(2), 95-102.

Cranswick, P., Raducescu, L., Hilton, G., Petkov, P., Isayeva, A., Sultanov, E., Georgiev, D., Iankov, P., Ivanov, I., Stefanov, T., Dereliev, S., Martin, K., Handrinos, G., Kastritis, T., Oláh, J., Brombacher, M., Koshkina, M., Sklyarenko, S., Timoshenko, A., Vilkov, V., Yerokhov, S., Bugariu, S., Petrescu, E., Fantana, C., Hulea, D., Marin, V., Szekely, P., Teodor, P., Anisimova, O., Badmaev, V., Derviz, D., Kharitonov, S., Litvin, K., Miliutina, M., Morozov, V., Popovkina, A. Pospelov, I., Poyarkov, N., Rozenfeld, S., Skuratov, N., Solokha, A., Syroechkovskiy, F., Tavares, J., Osadcha, O., Korzuykov, A., Rusev, I., Andryushchenko, Yu., Cook, N., \& Day, M. (2012). Draft international single species action plan for the conservation of the Red-Breasted Goose Branta ruficollis 20122022. European Commission and the Agreement on the Conservation of African-Eurasian Migratory Waterbirds (AEWA), La Rochelle.

DeGraaf, R. M., Tilghman, N. G., \& Anderson, S. H. (1985). Foraging guilds of North American birds. Environmental Management, 9(6), 493-536.

Dobrovolski, R., Melo, A. S., Cassemiro, F. A. S., \& Diniz, J. A. F. (2012). Climatic history and dispersal ability explain the relative importance of turnover and nestedness components of beta diversity. Ecology and Biogeography, 21, 191-197.

Dobrovolskyi, V. V. (2005). Ekologichni znannya [Ecological knowledge]. Profesional, Kyiv (in Ukrainian).

Dranga, A. O., Gorlov, P. I., Matsyura, A., \& Budgey, R. (2016). Breeding biology of rook (Corvus frugilegus) in the human transformed steppe ecosystems (the case of Botievo Wind Farm). Biological Bulletin of Bogdan Chmelnitskiy Melitopol State Pedagogical University, 6(1), 41-62.

Edenius, L., \& Sjoberg, K. (1997). Distribution of birds in natural landscape mosaics of oldgrowth forests in Northern Sweden: Relations to habitat area and landscape context. Ecography, 20, 425-431.

Ford, H. A., Barrett, G. W., Saunders, D. A., \& Recher, H. F. (2001). Why have birds in the woodlands of Southern Australia declined? Biological Conservation, 97, $71-88$.

Gentilli, J. (1968). Regions, natural and geographical. In: Fairbridge, R. W. (Ed.). The encyclopedia of geomorphology. Reinhold Book Corporation, New York. Pp. 932-933.

Hansson, L. (1994). Vertebrate distributions relative to clear-cut edges in a boreal forest landscape. Landscape Ecology, 9, 105-115.

Havrielenko, V. S., \& Lystopadskiy, M. A. (2012). Dendrofilna ornitofauna: Pytannia terminolohii ta ekolohichnoi klasyfikatsii (na prykladi ornitofauny Biosfernoho zapovidnyka "Askaniia-Nova") [Dendrophilous avifauna: Issues of terminology and ecological classification (on the example of avifauna of the Askania-Nova Biosphere Reserve)]. Ekolohiia ta Noosferolohiia, 23, 72-82 (in Ukrainian).

Heaney, L. R. (2001). Small mammal diversity along elevational gradients in the Philippines: An assessment of patterns and hypotheses. Global Change Biology, 10, 15-39.
Herrera, J. M., Salgueiro, P. A., Medinas, D., Costa, P., Encarnacao, C., \& Mira, A (2016). Generalities of vertebrate responses to landscape composition and configuration gradients in a highly heterogeneous Mediterranean region. Journal of Biogeography, 43, 1203-1214.

Hilden, O. (1965). Habitat selection in birds: A review. Annales Zoologici Fennici, 2, $54-75$.

Holt, B., Lessard, J. P., Borregaard, M. K., Fritz, S. A., Araujo, M. B., Dimitrov, D., Fabre, P. H., Graham, C. H., Graves, G. R., Jonsson, K. A., Nogues-Bravo, D., Wang, Z. H., Whittaker, R. J., Fjeldsa, J., \& Rahbek, C. (2013). An update of wallace's zoogeographic regions of the world. Science, 339, 74-78.

Hulbert, A. H. (2004). Species-energy relationships and habitat complexity in bird communities. Ecology Letters, 7, 714-720.

Ilyichev, V. D., Kartashev, N. N., \& Shilov, I. A. (1982). Obshhaya omitologiya [General ornithology]. Vysshaya Shkola, Moscow (in Russian).

Jamoneau, A., Passy, S. I., Soininen, J., Leboucher, T., \& Tison-Rosebery, J. (2018). Beta diversity of diatom species and ecological guilds: response to environmental and spatial mechanisms along the stream watercourse. Freshwater Biology, $63,62-73$.

Jankowski, J. E., Ciecka, A. L., Meyer, N. Y., \& Rabenold, K. N. (2009). Beta diversity along environmental gradients: Implications of habitat specialization in tropical montane landscapes. Journal of Animal Ecology, 78, 315-327.

Jetz, W., Wilcove, D. S., \& Dobson, A. P. (2007). Projected impacts of climate and land-use change on the global diversity of birds. PLoS One Biology, 5(6), 157.

Jiguet, F., Devictor, V., Ottvall, R., Van Turnhout, C., Van der Jeugd, H., \& Lindstrom, A. (2010). Bird population trends are linearly affected by climate change along species thermal ranges. Proceedings of the Royal Society of London, 277, 3601-3608

Jiguet, F., Gregory, R. D., Devitor, V., Green, R. E., Vorisek, P., van Strien, A., \& Couvet, D. (2010). Population trends of European common birds are predicted by characteristics of their climatic niche. Global Change Biology, 16, 497-505.

Jiguet, F., Julliard, R., Thomas, C. D., Dehorter, O., Newson, S. E., \& Couvet, D. (2006). Thermal range predicts bird population resilience to extreme high temperatures. Ecology Letters, 9, 1321-1330.

Karp, D. S., Frishkoff, L. O., Echeverri, A., Zook, J., Juarez, P., \& Chan, K. M. A (2018). Agriculture erases climate driven b-diversity in Neotropical bird communities. Global Change Biology, 24, 338-349.

Kochelev, V. O., \& Pakhomov, O. E. (2020). Ornitokompleksy yak strukturnyi element bioheotsenoziv: Struktura, kryterii, pokaznyky [Ornithocomplexes as a structural element of biogeocenoses: Structure, criteria, indicators]. Ecological Sciences, 28, 344-354 (in Ukrainian)

Koshelev, O. I., Koshelev, V. O., Fedushko, M. P., \& Zhukov, O. V. (2019). The bird communities diversity and indicator groups of natural and anthropogenic landscapes of the south and south-east of Ukraine. Agrology, 2(4), 229-240.

Koshelev, O., Koshelev, V., Fedushko, M., \& Zhukov, O. (2021). Annual course of temperature and precipitation as proximal predictors of birds' responses to climatic changes on the species and community level. Folia Oecologica, 48(2), $118-135$.

Koshelev, V. (2018). Hnizdovi omitokomplesy i funktsionalna rol ptakhiv v pishchanykh i hlynystykh karerakh na pivdni Zaporizkoi oblasti [Nesting omithocomplexes and the functional role of birds in sandy and clay quarries in the south of Zaporozhia region]. Biolohichnyi Visnyk Melitopolskoho Derzhavnoho Pedahohichnoho Universytetu imeni Bohdana Khmelnytskoho, 2, 20-31 (in Ukrainian).

Koshelev, V. A. (2017). Ornitokompleksyi trostnikovyih zarosley: Struktura, dinamika, problemyi ohranyi [Ornithocomplexes of reeds: The structure, dynamics, problems of protection]. Biologiya ta Valeologiya, 19, 16-27 (in Russian).

Kreft, H., \& Jetz, W. (2010). A framework for delineating biogeographical regions based on species distributions. Joumal of Biogeography, 37, 2029-2053.

Kricher, J. C. (1972). Bird species diversity: The effect of species richness and equitability on the diversity index. Ecology, 53(2), 278-282.

Krivulchenko, A. I. (2005). Sukhi stepy Prychomomoria ta Pryazovia: Landshafty, halokhimiia hrunto-pidhruntia [Dry steppes of the Prychornor'ya and Priazov'ya regions: Landscapes, halo-chemistry of soil-subsoil]. Hidromaks, Kyiv (in Ukrainian).

Legendre, P., Borcard, D., \& Peres-Neto, P. R. (2005). Analyzing beta diversity: Partitioning the spatial variation of community composition data. Ecological Monographs, $75,435-450$.

Lennon, J. J., Koleff, P., Greenwood, J. J. D., \& Gaston, K. J. (2001). The geographical structure of British bird distributions: Diversity, spatial turnover and scale. Journal of Animal Ecology, 70, 966-979.

Li, T., Chu, H., Qi, Y., Li, C., Ping, X., Sun, Y., \& Jiang, Z. (2019). Alpha and beta diversity of birds along elevational vegetation zones on the southern slope of $\mathrm{Al}$ tai Mountains: Implication for conservation. Global Ecology and Conservation, 19, e00643.

Ludwig, J. A., Eager, R. W., Liedloff, A. C., McCosker, J. C., Hannah, D., Thurgate, N. Y., Woinarski, J. C. Z., \& Catterall, C. P. (2000). Clearing and grazing impacts on vegetation patch structures and fauna counts in eucalypt woodland, Central Queensland. Pacific Conservation Biology, 6, 254-272. 
Lugovoi, A. E. (2007). O zoogeograficheskom statuse ozerno-morskikh poberezhij i ostrovov medial'noj chasti Palearktiki [On the zoogeographical status lake-sea coasts and islands of the medial part of the Palearctic]. Berkut, 16(2), 285-287 (in Russian).

MacArthur, R. H., \& MacArthur, J. W. (1961). On bird species diversity. Ecology, 42, 594-598.

McCain, C. M. (2004). The mid-domain effect applied to elevational gradients: Species richness of small mammals in Costa Rica. Journal of Biogeography, 31(1), 19-31.

Milkov, F. M. (1956). Lesostep' i step' Russkoj ravniny [Forest-steppe and steppe of the Russian Plain]. Izdatel'stvo AN SSSR, Moscow (in Russian).

Morante-Filho, J. C., Arroyo-Rodriguez, V., \& Faria, D. (2016). Patterns and predictors of beta-diversity in the fragmented Brazilian Atlantic forest: A multiscale analysis of forest specialist and generalist birds. Journal of Animal Ecology, 85, 240-250.

Negadi, M., Hassani, A., Hammou, M. A., Dahmani, W., Miara, M. D., Kharytonov, M., \& Zhukov, O. (2018). Diversity of diatom epilithons and quality of water from the subbasin of Oued Mina (district of Tiaret, Algeria). Ukrainian Journa of Ecology, 8(1), 103-117.

Pashchenko, V. M. (1999). Zonalno-rehionalnyi ohliad pryrodnykh landshaftiv rivnynnoji terytoriji Ukrainy [Zonal-regional view of natural landscapes of the plain territory of Ukraine]. In: Sheliah-Sosonko, Y. R. (Ed.). Development of eco-network of Ukraine. Tekhprynt, Kyiv. Pp. 26-36 (in Ukrainian).

Pendlebury, C. J., MacLeod, M. G., \& Bryant, D. M. (2004). Variation in temperature increases the cost of living in birds. Joumal of Experimental Biology, 207, 2065.

Perelman, A. I. (1975). Geokhimiya landshafta [Geochemistry of landscape]. Vysshaya Shkola, Moscow (in Russian).

Ponomarenko, O. L. (2004). Konsortyvni zviazky ptakhiv u dibrovakh stepovoho Prydniprovia yak faktor stiikosti lisovykh ecosystem [Consortium connections of birds in the oak groves of the steppe Dnieper region as a factor of sustainability of forest ecosystems]. DNU, Dnipropetrovsk (in Ukrainian).

Ponomarenko, O., Banik, M., \& Zhukov, O. (2021). Assessing habitat suitability for the common pochard, Aythya ferina (Anseriformes, Anatidae) at different spatial scales in Orel' river valley, Ukraine. Ekológia (Bratislava), 40(2), 154-162.

Poznanin, L. P. (1978). Ekologicheskie aspekty evolyuczii pticz [Ecological aspects of birds evolution]. Nauka, Moscow (in Russian).

Reimers, N. F. (1990). Prirodopol'zovanie: Slovar'-spravochnik [Nature use: Dictionary-reference]. Mysl', Moscow (in Russian).

Root, R. B. (1967). The niche exploitation pattern of the blue-gray gnatcatcher. Ecological Monographs, 37, 317-350.

Saniga, M. (1995). Breeding bird communities of the fir-beech to the dwarfed-pines vegetation tiers in the Vel'ká Fatra and Malá Fatra mountains. Biologia, Bratislava, 50(2), 185-193.

Shelford, V. E. (1913). Animal communities in temperate America as illustrated in Chicago Region. The Geographic Society of Chicago Bulletin, 5, 1-362.

Shelford, V. E., \& Towler, E. D. (1925). Animal communities on San Juan Channel and adjacent areas. Puget Sound Biological Station Publications, 5, 33-73.
Shulpin, L. M. (1940). Ornitologiya (stroenie, zhizn' i klassifikacziya pticz) [Ornithology (structure, life and classification of birds)]. Izdanie LGU, Leningrad (in Russian).

Si, X. F., Baselga, A., \& Ding, P. (2015). Revealing beta-diversity patterns of breeding bird and lizard communities on inundated land-bridge islands by separating the turnover and nestedness components. PLoS One, 10, 0127692.

Smith, V. G. (1928). Animal communities of a deciduous forest succession. Ecology, 9(4), 479-500.

Socolar, J. B., Gilroy, J. J., Kunin, W. E., \& Edwards, D. P. (2016). How should betadiversity inform biodiversity conservation? Trends in Ecolology and Evolution, 31, 67-80.

Tashliev, A. O. (1973). Ornitologicheskie kompleksy Yugo-Vostochnoj Turkmenii [Ornithological complexes of South-East Turkmenistan]. Ylym, Ashkhabad (in Russian).

Thomas, J. W., Miller, R. J., Maser, C., Anderson, R. G., \& Carter, B. E. (1979). Plant communities and successional stage. Agricultural Handbook, 553, 22-39.

Voinstvenskiy M. A. (1960). Pticzy stepnoj polosy Evropejskoj chasti SSSR [Birds of the steppe zone of the European part of the USSR]. AN USSR, Kiev (in Russian).

Watson, J. E. M., Whittaker, R. J., \& Dawson, T. P. (2004). Habitat structure and proximity to forest edge affect the abundance and distribution of forest-dependent birds in tropical coastal forests of Southern Madagascar. Biological Conservation, 120, 311-327.

Whittaker, R. H. (1960). Vegetation of the Siskiyou Mountains, Oregon and California. Ecological Monographs, 30, 279-338.

Whittaker, R. H. (1972). Evolution and measurement of species diversity. Taxonomy, 21, 213-251.

Willett, T. R. (2001). Spiders and other arthropods as indicators in old-growth versus logged redwood stands. Restoration Ecology, 9, 410-420.

Williams, R. J. (1990). Cattle grazing within subalpine heathland and grassland communities in the Bogong High Plains: Disturbance, regeneration and the shrubgrass balance. Proceedings of the Ecological Society of Australia, 16, 255-265.

Willson, M. F. (1974). Avian community organization and habitat structure. Ecology, 55, 1017-1029.

Wormworth, J., \& Mallon, K. (2010). Bird species and climate change. Climate Risk Pty Limited, Fairlight.

Zellweger, F., Roth, T., Bugmann, H., \& Bollmann, K. (2017). Beta diversity of plants, birds and butterflies is closely associated with climate and habitat structure. Global Ecology and Biogeography, 26, 898-906.

Zhukov, O. V. (2009). Ekomorfichni matrytsi mezafauny lisovykh hruntiv Stepovoho Prydniprov'ia [Ecomorphic matrices of meso-fauna of forest soils of the Steppe Dnieper region]. DNU, Dnipropetrovsk (in Ukrainian).

Zhukov, O. V., \& Potapenko, O. V. (2017). Fitindykatsiia ekolohichnykh umov u mezhakh terytorii elektrychnykh pidstantsii [Environmental impact assessment of distribution substations: The case of phytoindication]. Ukrainian Journal of Ecology, 7(1), 5-21 (in Ukrainian).

Zhukov, O., Kunah, O., Dubinina, Y., Zhukova, Y., \& Ganzha, D. (2019). The effect of soil on spatial variation of the herbaceous layer modulated by overstorey in an Eastern European poplar-willow forest. Ekologia (Bratislava), 38(3), 253-272. 